\title{
Determination of Benzene, Toluene and $N$-Hexane in Urine and Blood by Headspace Solid-Phase Microextration/Gas-Chromatography for the Biomonitoring of Occupational Exposure
}

\author{
Paulo C. F. de Lima Gomes, * Éverton D. D'Andrea, Camila B. Mendes \\ and Maria Elisa P. B. de Siqueira
}

Laboratório de Análises Toxicológicas, Universidade Federal de Alfenas, 37130-000 Alfenas-MG, Brazil

\begin{abstract}
A análise de tolueno, benzeno e $n$-hexano inalterados em urina e sangue humano é uma ferramenta para avaliar a exposição ocupacional a esses solventes. Um método simples usando microextração em fase sólida acoplada ao headspace (HS-SPME), usando fibras de carboxeno/ polidimetilsiloxano (CAR-PDMS) e PDMS, para análise simultânea por cromatografia gasosa de tolueno, benzeno e $n$-hexano em urina e em sangue foi desenvolvido com intuito de realizar a monitorização biológica de indivíduos expostos ocupacionalmente a esses solventes. O método foi aplicado na análise de amostras de trabalhadores que utilizavam colas, contendo solventes, na recuperação de calçados. O tolueno foi detectado em todas as amostras de sangue coletadas em sapatarias quando se utilizou a fibra de CAR-PDMS (16,0-55,2 $\left.\mu \mathrm{g} \mathrm{L}^{-1}, \mathrm{n}=7\right)$ e o $n$-hexano foi detectado em duas amostras $\left(33,0\right.$ and $\left.41,3 \mu \mathrm{g} \mathrm{L}{ }^{-1}\right)$. O benzeno não foi detectado em nenhuma das amostras de sangue e/ou urina. Nenhum dos solventes pode ser quantificado nas amostras de urina.
\end{abstract}

Analysis of unchanged toluene, benzene and $n$-hexane in human blood and urine can be useful to evaluate occupational exposure to these solvents. A simple method was developed using headspace-solid phase microextraction (HS-SPME) for simultaneous gas-chromatography analysis of toluene, benzene and $n$-hexane in urine and blood; with purpose of biological monitoring of occupational exposure. Carboxen/polidimethylsiloxane fiber (CAR-PDMS) and PDMS fiber coating were employed in this analysis. Blood and urine samples were collected from handling glue workers. The toluene was detected in all blood samples collected from workers handling glue in shoe repair shops, when using CAR-PDMS fibers (16.0-55.2 $\left.\mu \mathrm{g} \mathrm{L}^{-1}, \mathrm{n}=7\right) . n$-Hexane was only detected in two blood samples (33.0 and $41.3 \mu \mathrm{g} \mathrm{L}^{-1}$ ) and benzene was not detected in anyone. No solvent could be quantified in urine samples.

Keywords: SPME, $n$-hexane, toluene, benzene, urine, blood

\section{Introduction}

Volatile organic compounds (VOCs) presents vapor pressures above $0.01 \mathrm{kPa}$ and boiling points below $150^{\circ} \mathrm{C} .^{1,2}$ The determination of VOCs in inhaled air, blood, and urine is important from a toxicological, biochemical and forensic viewpoint. ${ }^{3,4}$

Organic solvents such as $n$-hexane, benzene, toluene and xylenes are present in a wide range of commercially available products because of their industrial use in the manufacturing of paints, adhesives, thinners, glues, plastic, pitch, bitumen, some pharmaceutical products and as intermediate in the formation of other chemical substances.

*e-mail: pauloclair@iqsc.usp.br
$n$-Hexane is one of the most important aliphatic compounds and is utilized as a solvent in several industries (i.e., pharmaceutical, chemical and shoe manufacturing) as ingredient in glues and during the manufacturing of polyolefins and rubber. Toxicological effects of $n$-hexane involve damage to the central and peripheral nervous systems. ${ }^{5-7}$

Exposure to benzene is less likely than that of $n$-hexane and toluene since its use as a solvent in industrial processes was banned in 1980.8,9 The International Agency for Research on Cancer (IARC) ${ }^{10}$ classified it as a potential carcinogenic type I. Then, the use of benzene is restricted to two situations. First, in synthetic processes, when benzene is an essential reagent and it is not possible to exchange for another one. Another situation is in the petrochemical 
industry, when present in the process of petroleum cracking. In addition, benzene can be encountered in cigarette smoke and after the combustion of fossil fuels, such as gasoline. The toxicological effects related to benzene are nonlymphocytic leukemia, ${ }^{11-13}$ aplastic anemia, chromosome aberrance ${ }^{14-17}$ and bone marrow progressive degeneration.

Toluene is a very common chemical which is widely used as a solvent in many consumer products, such as paints, glues and adhesives. Toluene is also used as a synthetic intermediate and as an additive in fuel to increase gasoline octane rating. It produces central nervous system toxicity and fetotoxicity. ${ }^{18}$

Human contamination by VOCs is generally evaluated by monitoring metabolites in urine. The 2,5-hexanodione, trans, trans muconic acid and hippuric acid are the main biomarkers of $n$-hexane, benzene and toluene, respectively. However, this procedure presents some disadvantages. Firstly, external sources such as food, mainly fruits and vegetables, can also contain these substances. Secondly, the urinary excretion of the metabolites is influenced by several factors such as age, alcohol consumption and smoking habits. Therefore, the quantity of biomarkers excreted varies depending on environmental factors and personal characteristics. ${ }^{19-22}$

In contrast, the use of unchanged solvents as biomarkers is more specific. The emergence and detection of solvents in urine and/or blood provides high selectivity since they are not endogenous substances. ${ }^{18}$

Solvents in urine are present in low concentrations as compared to blood..$^{23}$ Only about $0.06 \%$ of the absorbed toluene and $0.1-0.3 \%$ of benzene are excreted unchanged in the urine. Furthermore, the American Conference of Governmental Industrial Hygienist (ACGIH ${ }^{24}$ recommends the measurement of toluene in blood, where it is present in higher concentration, rather than in urine.

In toxicological analysis and other analytical procedures, sample preparation is an essential step to eliminate interferences and selectively extract analytes from the biological fluids. Solid phase microextraction (SPME) is a solventless extraction technique based on the sorption of the analyte in small diameter fibers coated with sorbent material. ${ }^{19,23}$ This technique involves two steps. First the analytes partition between the fiber coating and the sample matrix, followed secondly, by desorption of the concentrated extract into the analytical instrument. ${ }^{25}$ The headspace mode (HS-SPME) permits an efficient mass transfer and is better adapted for the analysis of volatile and semi-volatile chemical compounds, especially in complex matrices.

Other methods have been developed for the determination of solvents in blood and/or urine. ${ }^{19,23,26-31}$ However, in all these methods unaltered $n$-hexane was not included. Furthermore, there is no study dealing with simultaneous determination of unchanged $n$-hexane, benzene and toluene in blood and/or urine. It should be noted that simultaneous occupational exposure occurs more frequently than single exposure in industries that use products containing solvents.

This study focused on the development of a simple, sensitive, and environmental friendly HS-SPME/GCFID analytical method. Two different fiber coatings, polydimethylsiloxane (PDMS) and carboxen-PDMS (CAR-PDMS) were employed for the simultaneous determination of toluene, benzene and $n$-hexane in urine and blood. The method was applied to the analysis of the solvents in urine and blood of workers occupationally exposed in shoe repair shops.

\section{Experimental}

\section{Chemicals and standard solutions}

n-Hexane (99.9\%) (Biotec, Pinhais, Brazil), benzene $(99.9 \%)$, toluene $(99.9 \%)$, isooctane $(99.9 \%)$ and ethylbenzene (99.9\%) (Grupo Química, Penha, Brazil) and sodium chloride (Neon Comercial Ltda., Ipiranga, Brazil) were used. Stock solutions of each of the above organic compounds were prepared in methanol (Mallinckrodt Baker Inc., Phillipsburg, USA) at a concentration of $1000 \mathrm{mg} \mathrm{L}^{-1}$, and stored at $4{ }^{\circ} \mathrm{C}$ in sealed amber vial until use.

\section{Instruments}

A manual SPME device (Bellefonte, PA, USA) was used to hold the fiber. Fibers coated with PDMS $(100 \mu \mathrm{m}$ thickness) and CAR-PDMS (75 $\mu \mathrm{m}$ thickness) were purchased from Supelco. A 1-cm magnetic bar (Supelco) and water bath with digital temperature control (B. Braun Biotech International $\mathrm{GmbH}$, Melsungen, Germany) were used in the SPME procedure. Glass vials, $16 \mathrm{~mL}$, sealed with silicone/PTFE septa were also obtained from Supelco and used for HS-SPME extraction.

A GC 1000 gas-chromatograph with a FID detector (Ciola Gregori Ltda., São Paulo, Brazil) equipped with a splitless injector inlet liner, interfaced to a PC with a DANI DS 1000 integrator (Dani Strumentazione Analitica, Monza, Italy) and IQ3 software for data acquisition was used. The injections were conducted in splitless mode.

\section{Chromatographic conditions}

In order to obtain an effective separation between toluene, benzene, $n$-hexane and endogenous compounds 
present in urine and blood five columns with different characteristics were tested: HP-1 dimethylsiloxane, HPInnowax polyethylene glycol both with $30 \mathrm{~m} \times 0.53 \mu \mathrm{m}$ i.d. $\times$ $0.5 \mu \mathrm{m}$ film thickness and HP-1U methylsiloxane $30 \mathrm{~m} \times$ $0.32 \mu \mathrm{m} \times 0.25 \mu \mathrm{m}$ from Agilent Technologies (Santa Clara, CA, USA); ZB-35 phenyl polysiloxane $30 \mathrm{~m} \times 0.53 \mu \mathrm{m} \times$ $0.5 \mu \mathrm{m}$ and ZB-1 PDMS $30 \mathrm{~m} \times 0.53 \mathrm{~mm} \times 5.0 \mu \mathrm{m}$ from Zebron (Newport Beach, CA, USA). Different temperature programs were tested as well. Nitrogen was used as carrier gas at a constant flow of $2.5 \mathrm{~mL} \mathrm{~min}{ }^{-1}$; the detector was maintained at $250{ }^{\circ} \mathrm{C}$ and the injector at $240{ }^{\circ} \mathrm{C}$ or $260{ }^{\circ} \mathrm{C}$ for PDMS, and CAR-PDMS fiber respectively.

\section{HS-SPME variables}

The HS-SPME variables were optimized to obtain the best resolution and efficiency. For each coating phase the following parameters were studied: heating temperature, stirring time, fiber headspace exposure time and sodium chloride concentration in the matrix. Desorption of analytes from the fibers (time and temperature of the injector port) was also established.

\section{HS-SPME procedure}

Eight milliliters of urine or two milliliter of blood, previous homogenized, were transferred to $16 \mathrm{~mL}$ vials containing a magnetic stir bar and an adequate amount of sodium chloride. The vials were sealed with a silicone/ PTFE septum to prevent any loss of the analytes and kept heated in a thermoblock under constant stirring. After reaching equilibrium the septum was pierced with a SPME needle and the SPME fiber was exposed to the headspace for sorption of the volatile compounds. Subsequently, the SPME fiber was transferred to the GC injector for desorption.

\section{Analytical validation}

The chromatographic co-elution of isooctane, ethylbenzene, methanol, ethanol, acetone, pyridine, xylenes, cyclohexane, heptanes, 2-methylhexanone, isopropylic alcohol and methylethylbutylketone were evaluated by direct injection of these compounds into the GC.

Calibration curves were obtained spiking blank urine samples with six different concentrations of each solvent (5 replicates per concentration): toluene between 92 and $560 \mu \mathrm{g} \mathrm{L}^{-1}$, benzene between 2 and $420 \mu \mathrm{g} \mathrm{L}-1$ and $n$-hexane between 10 and $540 \mu \mathrm{g} \mathrm{L}^{-1}$ when CAR-PDMS fibers were used. The same procedure was adopted for PDMS fibers, however the concentrations of toluene, benzene and $n$-hexane ranged from 92 to $2000 \mu \mathrm{L} \mathrm{L}^{-1}$, from 2 to 6000 and from 10 to $10000 \mu \mathrm{g} \mathrm{L}^{-1}$, respectively.

For blood, a similar procedure was used (six different concentrations of each solvent, 5 replicates per concentration). The concentrations ranged from 16.6 to $1000 \mu \mathrm{g} \mathrm{L} \mathrm{L}^{-1}$ for toluene and from 33.2 to $2000 \mu \mathrm{g} \mathrm{L}^{-1}$ for benzene and $n$-hexane when CAR-PDMS fibers were used. The same procedure was adopted for PDMS fibers. However, the concentrations of toluene and benzene varied between 50 and $1000 \mu \mathrm{g} \mathrm{L}^{-1}$ and $n$-hexane between 100 and $2000 \mu \mathrm{g} \mathrm{L} \mathrm{L}^{-1}$.

The lowest and highest values of the linear range for each analyte were defined taking into account the LOQ (limit of quantification) and the detector sensitivity response to each solvent. Isooctane was used as an internal standard for urine samples and ethylbenzene for bloods samples.

The linear regression was calculated by the least mean square method. Quantification limit (LOQ) was established as the concentration that provides an analytical signal ten times higher than noise with adequate precision (RSD $<20 \%$ ). The LOQ for each solvent was the first concentration in the calibration curves. The intra-assay and inter-assay precision was estimated using spiked samples of urine or blood in five replicates at three concentrations levels within the linearity range.

\section{Biological samples}

Urine and blood samples were collected from healthy, non-smoking volunteers unexposed to VOC's (blank samples) for method optimization and validation. Samples from workers handling leather glue in shoe repair shops were obtained from seven volunteers and collected at the end of their work shift. Spot urine specimens were collected directly from the donor in $50 \mathrm{~mL}$ polyethylene vials. Aliquots of $8 \mathrm{~mL}$ from each sample were immediately transferred to headspace vials containing the internal standard and salt and then sealed. Blood was collected in a disposable system (BD Vacuntainer $^{\circledR}$, Franklin Lakes, NJ, USA) and $2 \mathrm{~mL}$ aliquots were taken and treated as described for urine. The collection of urine and blood was in agreement with criteria established by the Ethics Committee of the Federal University of Alfenas (Unifal-MG).

\section{Results and Discussion}

Most of the published methods for analysis of unaltered solvents in biological fluids use GC/MS. There are few reported methods using HS-SPME followed by GC/FID to evaluate occupational exposure, no one for $n$-hexane. 
Lee et al. ${ }^{27}$ evaluated the occupational exposure of benzene and toluene in urine and blood, but analyzing these compounds in rat blood and urine. Alegretti et al..$^{23}$ quantified benzene, toluene and xylenes in whole blood to evaluated extreme exposure in inhalants addicts. Asakawa et al. ${ }^{26}$ measured the occupational exposure of toluene and xylenes in urine of plastic films industry worker's. Moreover, poor epidemiological data about occupational exposure of Brazilian's shoes workers were found in the literature.

\section{Optimization of the chromatographic conditions}

An adequate resolution was obtained using the ZB-1 megabore column $(30 \mathrm{~m} \times 0.53 \mathrm{~mm}$ i.d. $\times 5 \mu \mathrm{m}$ film thickness). Oven temperature was kept at $80^{\circ} \mathrm{C}$ for $3 \mathrm{~min}$ and then heated at a rate of $10^{\circ} \mathrm{C} \mathrm{min}{ }^{-1}$ until reaching $150{ }^{\circ} \mathrm{C}$. The temperature was maintained at $150{ }^{\circ} \mathrm{C}$ for $3.2 \mathrm{~min}$ and then raised to $220^{\circ} \mathrm{C}$ at a rate of $40^{\circ} \mathrm{C} \mathrm{min}^{-1}$ and then held for $6 \mathrm{~min}$. Desorption was set at $240^{\circ} \mathrm{C}$ for $5 \mathrm{~min}$ (PDMS fiber) or at $260^{\circ} \mathrm{C}$ for $10 \mathrm{~min}$ (CAR-PDMS fiber), which allowed a complete desorption, without carryover.

Better resolution among analytes and endogenous components from urine and blood as well as minimum peak tailing were observed under the optimized conditions. Moreover, ZB-1 presented an adequate film thickness and hydrophobic phase which allowed better separation when compared to the other columns tested. Figures 1 and 2 present chromatograms of blank urine and blood samples, respectively. In both chromatograms no interfering peaks from endogenous compounds were observed among the analytes retention times (6-12 $\mathrm{min})$.

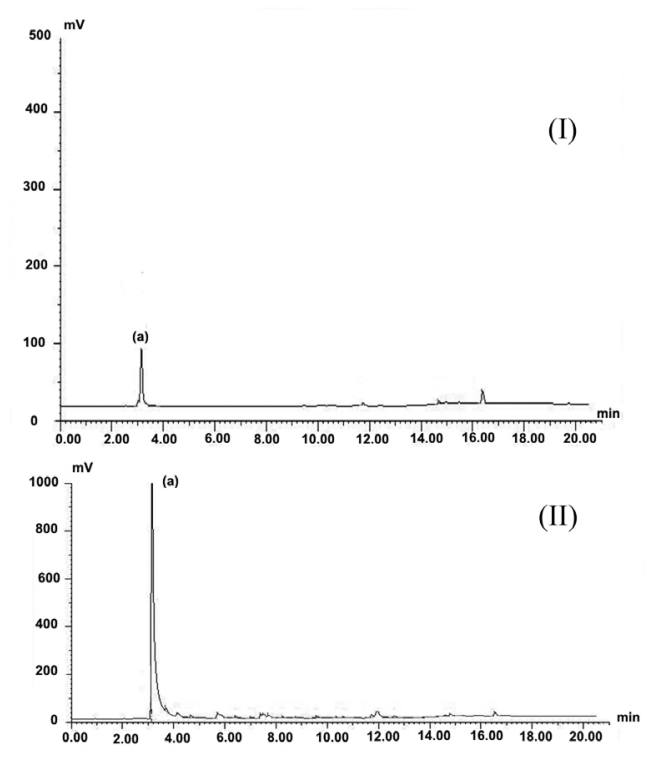

Figure 1. Chromatogram of blank urine extracted by PDMS fiber (I) and by CAR-PDMS (II), spiked with $200 \mu \mathrm{L}$ methanol(a).

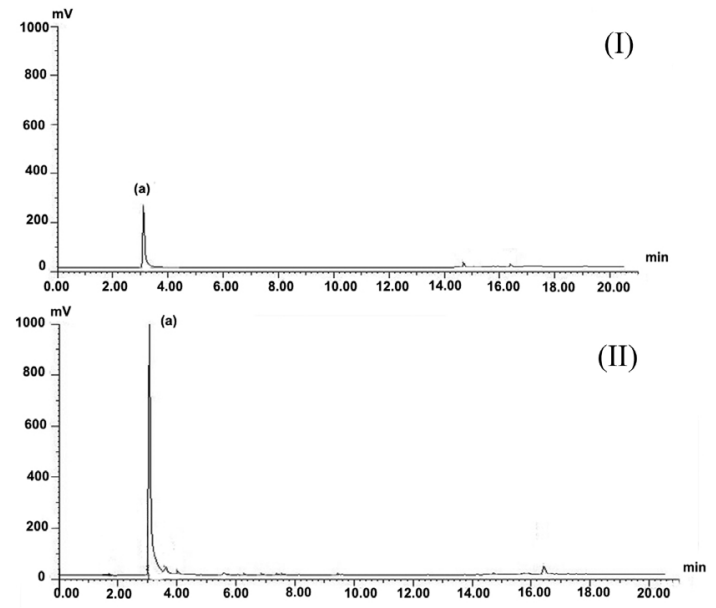

Figure 2. Chromatogram of blank blood extracted by PDMS fiber (I) and by CAR-PDMS fiber (II), containing $50 \mu \mathrm{L}$ de methanol(a).

Figures 3 and 4 show chromatograms of spiked urine and blood, respectively. The peaks obtained with CARPDMS fibers show peak tailing, which can be attributed to the slower desorption rate from this fiber. However, significantly greater responses were obtained with CARPDMS fibers when compared with PDMS fibers.

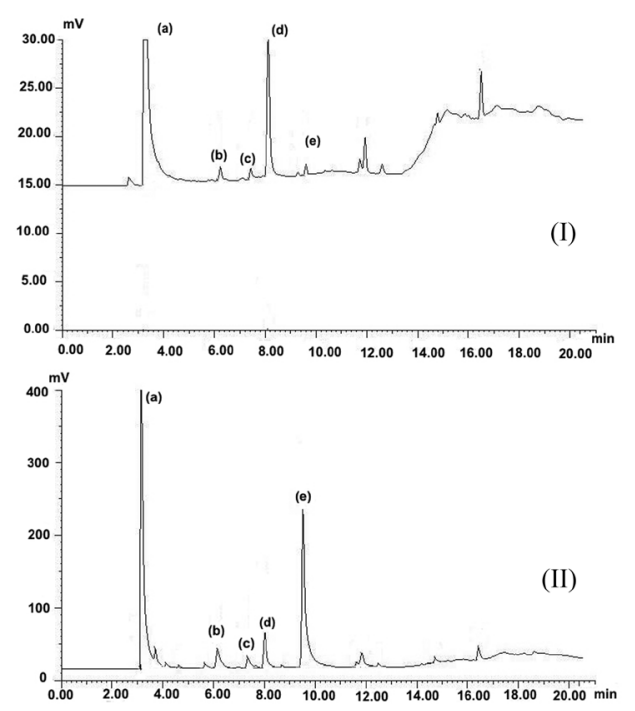

Figure 3. Chromatogram (I) of spiked urine extracted by PDMS fiber with $50 \mu \mathrm{g} \mathrm{L}-1$ of $n$-hexane (b), $24 \mu \mathrm{g} \mathrm{L}{ }^{-1}$ of benzene (c), $92 \mu \mathrm{g} \mathrm{L}-1$ of toluene (e) and $360 \mu \mathrm{g} \mathrm{L}^{-1}$ of isooctane (d). Typical chromatogram (II) of spiked urine extracted by CAR-PDMS fiber with $10 \mu \mathrm{g} \mathrm{L}^{-1}$ of $n$-hexane (b), $2.0 \mu \mathrm{g} \mathrm{L}^{-1}$ of benzene (c), $92 \mu \mathrm{g} \mathrm{L}^{-1} \mathrm{o}$ f toluene (e) and $2000 \mu \mathrm{g} \mathrm{L}^{-1}$ of isooctane (d).

\section{HS-SPME conditions}

Table 1 summarize the variables studied and the ones selected as optimum for each solvent in urine and blood respectively.

A great number of fiber phases are commercially available today. PDMS fibers have been largely used to 


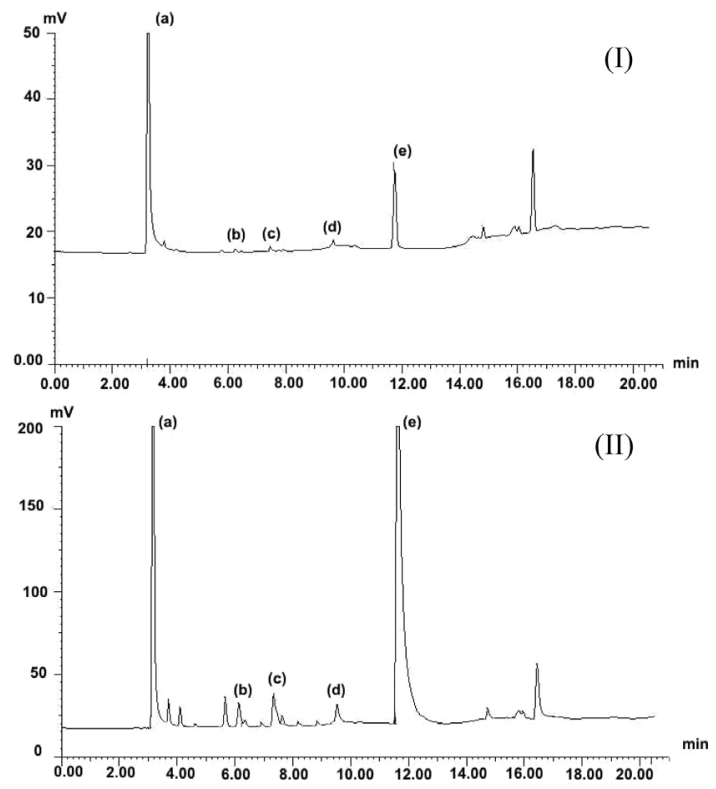

Figure 4. Typical chromatogram (I) of spiked blood extracted by PDMS fiber with $100 \mu \mathrm{g} \mathrm{L}^{-1}$ of $n$-hexane (b), and benzene (c), $50 \mu \mathrm{g} \mathrm{L}^{-1}$ toluene (d) and $2000 \mu \mathrm{g} \mathrm{L}^{-1}$ of ethylbenzene (e). Chromatogram (II) of spiked blood extracted by CAR-PDMS with $33.8 \mu \mathrm{g} \mathrm{L}^{-1}$ of $n$-hexane (b) and benzene (c), $16.8 \mu \mathrm{g} \mathrm{L}^{-1}$ toluene (d) and $2000 \mu \mathrm{g} \mathrm{L}-1$ of ethylbenzene (e).

extract various analytes, especially VOCs, while CARPDMS fibers have also been utilized in analysis of VOCs, particularly in trace analysis. ${ }^{27,32-34}$

The mechanism of extraction varies depending on the type of coating used. PDMS coating is one of the most widely used coatings for extracting volatile compounds because of the relative ease of extraction by absorption, which is not affected by competition between analytes. This process depends on the partition coefficient sample/ headspace. At the same time, coating thickness and molecular size of analyte will determine the capacity of absorption on the fiber. ${ }^{1}$

On the other hand, the sensitivity of mixed-phase SPME coatings, such as CAR-PDMS, is reported to be much higher compared to PDMS for extracting volatile compounds. ${ }^{32,33}$ In addition, CAR-PDMS coated fibers exhibit micro and mesopores with 2-20 A diameter, appropriate for extracting compounds, such as solvents, containing 2-12 carbons in their molecular structures. These coatings extract primarily via adsorption into the fiber coating and require more time to reach equilibrium or saturation of the pores. The results showed in Table 1 demonstrate the higher sorption time of CAR-PDMS compared to PDMS fibers. Also, different desorption times and temperatures emphasize these properties: CARPDMS fibers required $10 \mathrm{~min}$ at $260^{\circ} \mathrm{C}$ for complete desorption, without carryover, while PDMS required only $5 \mathrm{~min}$ at $240{ }^{\circ} \mathrm{C}$. Despite this higher sorption time, greater amounts of volatile and semi-volatile compounds were extracted by CAR-PDMS compared to PDMS. The competitive adsorption and displacement effects make mass equilibrium and quantification particularly challenging, as observed in the narrow linear range of CAR-PDMS compared with PDMS fibers ${ }^{35}$ (see Tables 2 and 3).

\section{Method validation}

Tables 2 and 3 report the validation parameters established for urine and blood respectively. For urine, $\mathrm{R}^{2}$ values $>0.99$ were obtained for all solvents, regardless of the fiber type. For blood samples $\mathrm{R}^{2}$ values $>0.99$ were obtained, except for toluene $\left(\mathrm{R}^{2}=0.98\right)$ in PDMS fibers. Variation of coefficients lower than $17 \%$ was observed for both fibers. These results are in accordance with ANVISA, ${ }^{36}$ FDA $^{37}$ and IUPAC ${ }^{38}$ requirements.

The higher slope associated with PDMS fibers indicates better sensitivity when using this coating for urine analysis. However, CAR-PDMS demonstrated better detectability and lower LOQ values compared to the PDMS fibers. The LOQ values for blood samples were higher than those for urine since blood contains endogenous hydrophobic substances, which have an affinity to these solvents, making volatilization of the analytes more difficult. The sample volumes of $8 \mathrm{~mL}$ for urine and $2 \mathrm{~mL}$ for blood were

Table 1. Levels of the HS-SPME parameters evaluated during univariate optimization for urine and blood samples

\begin{tabular}{|c|c|c|c|c|c|}
\hline \multicolumn{3}{|c|}{ Urine } & \multicolumn{3}{|c|}{ Blood } \\
\hline \multirow[t]{2}{*}{ Variables } & \multicolumn{2}{|c|}{ Values } & \multirow[t]{2}{*}{ Variables } & \multicolumn{2}{|c|}{ Values } \\
\hline & PDMS & CAR-PDMS & & PDMS & CAR-PDMS \\
\hline Heating temperature $/{ }^{\circ} \mathrm{C}$ & $25^{*}, 30,35$ & $25^{*}, 30,35$ & Heating temperature $/{ }^{\circ} \mathrm{C}$ & $26^{*}, 28,33$ & $26,30^{*}, 35,40$ \\
\hline Stirring time / min & $5^{*}, 10,20$ & $5^{*}, 10,15$ & Stirring time / min & $5,10,20^{*}, 30$ & $10^{*}, 20,30$ \\
\hline $\begin{array}{l}\text { Amount of sodium } \\
\text { chloride / g }\end{array}$ & $0.12 ; 0.50 ; 0.75^{*} ; 1.0$ & $0.12 ; 0.50 * ; 0.75$ & $\begin{array}{l}\text { Amount of sodium } \\
\text { chloride / g }\end{array}$ & $2,4^{*}, 6$ & $2^{*}, 4,6$ \\
\hline Fiber sorption time / min & $2,5^{*}, 10$ & $5,10,12^{*}, 15,20$ & Fiber sorption time / min & $2^{*}, 4,6$ & $5,10,12 *, 15,20$ \\
\hline
\end{tabular}

*Optimized values. 
Table 2. Validation data obtained for the solvents analysis in urine samples

\begin{tabular}{|c|c|c|c|c|c|c|c|c|c|c|}
\hline \multirow[t]{3}{*}{ Compound } & \multirow{2}{*}{\multicolumn{2}{|c|}{$\begin{array}{c}\text { Linearity range / } \\
\left(\mu \mathrm{g} \mathrm{L}^{-1}\right)\end{array}$}} & \multirow{2}{*}{\multicolumn{2}{|c|}{$\begin{array}{l}\text { Regression data } \\
(\mathrm{a}, \mathrm{b}, \mathrm{r})\end{array}$}} & \multirow[t]{3}{*}{ Level } & \multirow{2}{*}{\multicolumn{2}{|c|}{$\begin{array}{c}\text { Precision / }(\% \mathrm{CV}) \\
\text { Intra-assay }\end{array}$}} & \multicolumn{3}{|c|}{ Precision / (\%CV) } \\
\hline & & & & & & & & Day1 & Day2 & Day3 \\
\hline & PDMS & $\begin{array}{r}\text { CAR- } \\
\text { PDMS }\end{array}$ & PDMS & $\begin{array}{r}\text { CAR- } \\
\text { PDMS }\end{array}$ & & PDMS & $\begin{array}{l}\text { CAR- } \\
\text { PDMS }\end{array}$ & & CAR-P & $\mathrm{MS}$ \\
\hline$n$-hexane & $10-10000$ & $1-540$ & $\begin{array}{r}-0.1163 \\
0.7925 \\
0.9984\end{array}$ & $\begin{array}{l}0.2995 \\
0.0172 \\
0.9954\end{array}$ & $\begin{array}{l}\text { Low } \\
\text { Medium } \\
\text { High }\end{array}$ & $\begin{array}{c}11 \\
10 \\
7.0\end{array}$ & $\begin{array}{l}15 \\
10 \\
9.3\end{array}$ & $\begin{array}{l}1.9 \\
6.8 \\
9.3\end{array}$ & $\begin{array}{l}14 \\
10 \\
9.3\end{array}$ & $\begin{array}{l}11 \\
4.3 \\
0.3\end{array}$ \\
\hline benzene & $2-6000$ & $2-420$ & $\begin{array}{r}-0.0882 \\
1.6276 \\
0.9977\end{array}$ & $\begin{array}{r}-1.5559 \\
0.0358 \\
0.9959\end{array}$ & $\begin{array}{l}\text { Low } \\
\text { Medium } \\
\text { High }\end{array}$ & $\begin{array}{c}13 \\
13 \\
4.9\end{array}$ & $\begin{array}{l}11 \\
9.3 \\
11\end{array}$ & $\begin{array}{l}10 \\
9.1 \\
11\end{array}$ & $\begin{array}{l}12 \\
9.3 \\
11\end{array}$ & $\begin{array}{r}7.1 \\
6.7 \\
14\end{array}$ \\
\hline toluene & $92-2000$ & $92-560$ & $\begin{array}{l}-0.3524 \\
3.769 \\
0.9955\end{array}$ & $\begin{array}{r}-3.515 \\
0.0431 \\
0.9956\end{array}$ & $\begin{array}{l}\text { Low } \\
\text { Medium } \\
\text { High }\end{array}$ & $\begin{array}{l}11 \\
12 \\
8.9\end{array}$ & $\begin{array}{r}8.3 \\
10 \\
11\end{array}$ & $\begin{array}{l}10 \\
13 \\
11\end{array}$ & $\begin{array}{c}8.3 \\
10 \\
11\end{array}$ & $\begin{array}{l}11 \\
11 \\
15\end{array}$ \\
\hline
\end{tabular}

PDMS: $\mathrm{a}=$ intercept, $\mathrm{b}=$ slope, $\mathrm{r}=$ correlation coefficient. Low level $=10 \mu \mathrm{g} \mathrm{\textrm {L } ^ { - 1 }} n$-hexane and benzene, $92 \mu \mathrm{g} \mathrm{L}^{-1}$ toluene. Medium level $=2500 \mu \mathrm{g} \mathrm{L}^{-1}$ $n$-hexane, $1500 \mu \mathrm{g} \mathrm{L}{ }^{-1}$ benzene, $500 \mu \mathrm{g} \mathrm{L} \mathrm{L}^{-1}$ toluene. High level $=10000 \mu \mathrm{g} \mathrm{L}{ }^{-1} n$-hexane, $6000 \mu \mathrm{g} \mathrm{L}{ }^{-1}$ benzene, $2000 \mu \mathrm{g} \mathrm{L}^{-1}$ toluene. CAR-PDMS:

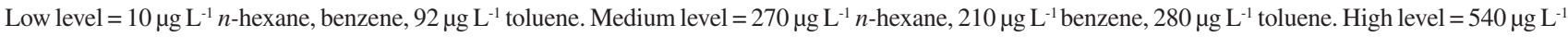
$n$-hexane, $420 \mu \mathrm{g} \mathrm{L}^{-1}$ benzene, $560 \mu \mathrm{g} \mathrm{L} \mathrm{L}^{-1}$ toluene.

Table 3. Validation data obtained for the solvents analysis in blood samples

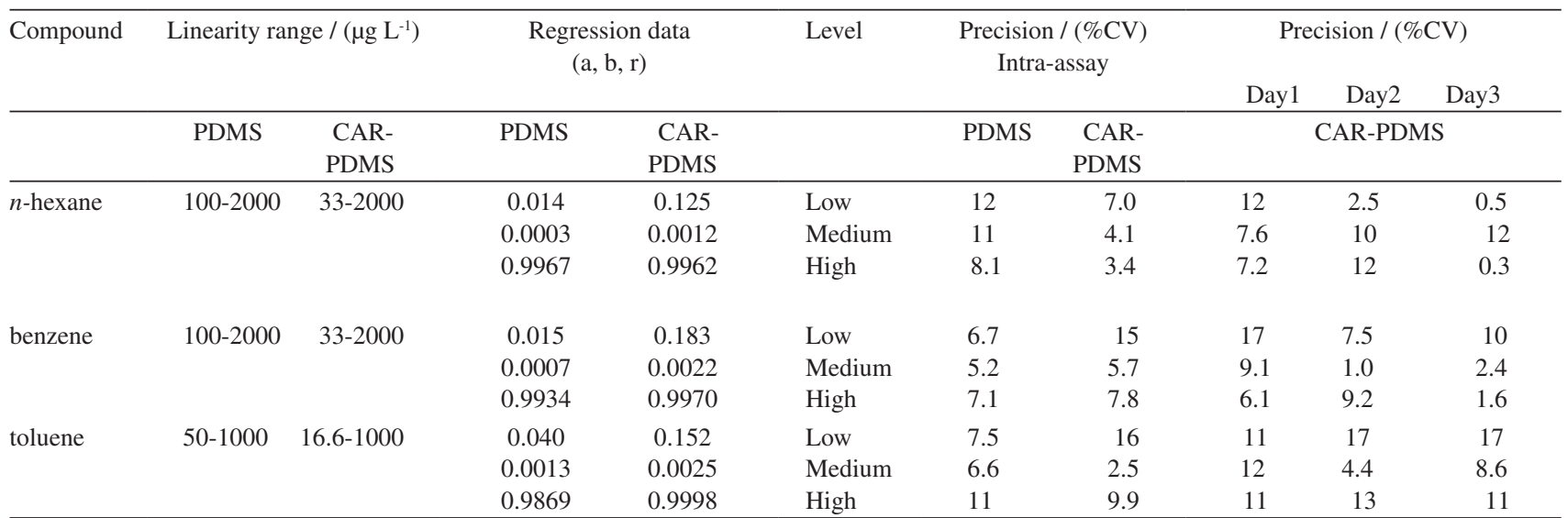

PDMS: $a=$ intercept, $\mathrm{b}=$ slope, $\mathrm{r}=$ correlation coefficient. Low level $=100 \mu \mathrm{g} \mathrm{L}{ }^{-1} n$-hexane, benzene, $50 \mu \mathrm{g} \mathrm{L}{ }^{-1}$ toluene. Medium level $=500 \mu \mathrm{g} \mathrm{L}{ }^{-1} n$-hexane and benzene, $250 \mu \mathrm{g} \mathrm{L}^{-1}$ toluene. High level $=2000 \mu \mathrm{g} \mathrm{L}^{-1} n$-hexane and benzene, $1000 \mu \mathrm{g} \mathrm{L}{ }^{-1}$ toluene. CAR-PDMS: Low level $=33 \mu \mathrm{g} \mathrm{L}^{-1} n$-hexane and benzene, $16 \mu \mathrm{g} \mathrm{L}^{-1}$ toluene Medium level $=500 \mu \mathrm{g} \mathrm{L}^{-1} n$-hexane and benzene, $250 \mu \mathrm{g} \mathrm{L}^{-1}$ toluene. High level $=2000 \mu \mathrm{g} \mathrm{L}-1$ $1000 \mu \mathrm{g} \mathrm{L} \mathrm{L}^{-1}$ toluene.

selected to obtain a lower LOQ. In the case of blood it is not recommended to use a large sample volume due to the invasive procedure of sampling.

\section{Samples from occupationally exposed workers}

The validated method was applied to the determination of toluene, benzene and $n$-hexane in urine and blood collected from seven shoe workers who handle glues containing solvents, mainly toluene and $n$-hexane. In blood samples, the use of CAR-PDMS fibers allowed the quantification of toluene (from 16.0 to $55.2 \mu \mathrm{g} \mathrm{L}^{-1}$ ) in all samples. Only one blood sample presented result for toluene when using PDMS fiber $\left(53.9 \mu \mathrm{g} \mathrm{L}^{-1}\right)$. The biological exposure index (BEI) for toluene in blood, as recommended by the $\mathrm{ACGIH}$, is $50 \mu \mathrm{g} \mathrm{L}^{-1}$. This represents the maximum allowable blood concentration which presents no risk for the majority of workers exposed to the solvent in an occupational environment. Only one worker presented blood toluene higher than the allowable BEI, while the other workers were within acceptable exposure levels. Figure 5 shows a chromatogram of the analysis of blood sample from a shoe worker.

Benzene was not detected in any sample, regardless the use or not of cigarette by the worker. Although the levels of the solvent in biological fluids of smokers are higher than in the non smokers, concentrations varying between 191-942 $\mathrm{ng} \mathrm{L}^{-1}$ in urine ${ }^{39}$ and 81-1136 ng L-1 in blood. ${ }^{40}$ The LOQ of the method used is higher than its detection in situations of environmental or smoking exposure. On the other hand, as mentioned earlier, benzene was banned as an additive in glues long time ago. 


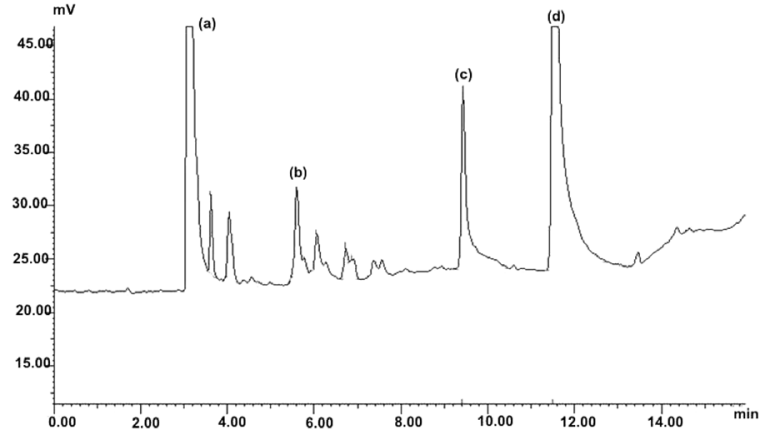

Figure 5. Chromatogram of shoe worker's blood containing $33 \mu \mathrm{g} \mathrm{L}^{-1}$ of $n$-hexane (b) $55.2 \mu \mathrm{g} \mathrm{L}^{-1}$ of toluene (c) and $2000 \mu \mathrm{g} \mathrm{L}^{-1}$ of ethylbenzene (d) as internal standard.

$n$-Hexane was detected in blood from only two volunteers (33.0 and $\left.41.3 \mu \mathrm{g} \mathrm{L}^{-1}\right)$. Imbriani and coworkers $^{39,41,42}$ reported that the urine concentration of unaltered $n$-hexane corresponding to the TLV-TWA (50 ppm, ACGIH) was $13.09 \mu \mathrm{g} \mathrm{L}^{-1}$, not mentioning the corresponding value for blood samples. Although no positive results were obtained for $n$-hexane in the urine samples from exposed workers, the LOQ established for both fibers permits its use for analysis at concentrations lower than the reported biological limit. At present, there is no established biological limit value for unaltered benzene in urine or blood. No solvent could be detected in any urine sample, regardless of the fiber type.

\section{Conclusions}

The HS-SPME analytical method proposed for toluene, benzene and $n$-hexane analysis in blood and urine is highly sensitive and specific and can be performed with equipment available in most laboratories (HS/SPME-GC/FID). The LOQ, precision and linearity obtained support its usefulness in routine biomonitoring analysis, with CAR-PDMS fibers, having lower levels of detection for solvent exposure and is recommended for blood analysis.

\section{Acknowledgments}

The authors would like to thank the financial support from $\mathrm{CNPq}$ (Conselho Nacional de Desenvolvimento Científico e Tecnológico) and the grant provided by Fapemig (Fundação de Auxílio à Pesquisa do Estado de Minas Gerais).

\section{References}

1. Parreira, F. V.; Cardeal, Z. d. L.; Quim. Nova 2005, 28, 646.

2. Keith, L. H.; Principles of Environmental Sampling, $2^{\text {th }}$ ed., ACS: Washington, 1996.
3. Statheropoulos, M.; Sianos, E.; Agapiou, A.; Georgiadou, A.; Pappa, A.; Tzamtzis, N.; Giotaki, H.; Papageorgiou, C.; Kolostoumbis, D.; J. Chromatogr., B 2005, 822, 112.

4. Mills, G. A.; Walker, V.; J. Chromatogr., A 2000, 902, 267.

5. Hamelin, G.; Truchon, G.; Tardif, R.; Int. Arch. Occup. Environm. Health 2004, 77, 264.

6. Spencer, P. S.; Schaumburg, H. H.; Sabri, M. I.; Veronesi, B.; Crit. Rev. Toxicol. 1980, 7, 279.

7. Graham, D. G.; Amarnath, V.; Valentine, W. M.; Pyle, S. J.; Anthony, D. C.; Crit. Rev. Toxicol. 1995, 25, 91

8. ANP - AGÊNCIA NACIONAL DE PETRÓLEO BRASIL, MINISTÉRIO DO TRABALHO (MT) \& MINISTÉRIO DA SAÚDE (MS) - Portaria Ministerial n³, 28 de abril, 1982.

9. ANVISA, Diário Oficial da União, RDC ANVISA No 252, (1609-2003), http://e-legis.anvisa.gov.br/leisref/public/showAct. php?id=8127, accessed in January 2009.

10. IARC Monographs; Evaluation of Carcinogenic Risks to Humans, 1987, vol. 1-42, suppl. 7, 120.

11. Ott, M. G., Townsend, J. C., Fishbeck, W. A., Langner, R. A.; Arch. Environ. Health 1978, 33, 3.

12. Rinsky, R. A.; Environ. Health Perspect. 1989, 82, 189.

13. Aksoy, M.; Environ. Health Perspect. 1989, 82, 193.

14. Basilicata, P.; Miraglia, N.; Pieri, M.; Acampora, A.; Soleo, L.; Sannolo, N.; J. Chromatogr., B 2005, 818, 293.

15. Hite, M.; Pecharo, M.; Smith, I.; Thornton, S.; Mutat. Res. 1980, $77,149$.

16. Forni, A.; Environ. Health Perspect. 1996, 104, 1309.

17. Tice, R. R.; Costa, D. L.; Drew, R. T.; Proc. Natl. Acad. Sci. U. S. A. 1980, 77, 2148.

18. Fustinoni, S.; Buratti, M.; Giampiccolo, R.; Brambilla, G.; Foà, V.; Colombi, A.; Int. Arch. Occup. Environm. Health 2000, 73, 389.

19. Kramer Alkalde, T.; do Carmo Ruaro Peralba, M.; Alcaraz Zini, C.; Bastos Caramao, E.; J. Chromatogr., A 2004, 1027, 37.

20. Rolle-Kampczyk, U.; Herbarth, O.; Rehwagen, M.; J. Environ. Med. 1999, 1, 65.

21. Kumar, S.; Tiwari, G. N.; Singh, H. N.; Desalination 2000, 127, 79.

22. Alvarez-Leite, E. M.; Duarte, A.; Barroca, M. M.; Silveira, J. N.; J. Occup. Health 1999, 41, 112.

23. Alegretti, A. P.; Thiesen, F. V.; Maciel, G. P.; J. Chromatogr., B 2004, 809, 183.

24. American Conference of Governmental Industrial Hygienists (ACGIH), Thershold Limit Values and Biological Exposure Indices for 2006, ACGIH: Cincinatti, 2006.

25. Fernandes, C.; Neto, A. J. d. S.; Rodrigues, J. C.; Alves, C.; Lancas, F. M.; J. Chromatogr., B 2007, 847, 217.

26. Asakawa, F.; Jitsunari, F.; Choi, J.; Suna, S.; Takeda, N.; Kitamado, T.; Bull. Environ. Contam. Toxicol. 1999, 62, 109.

27. Lee, X.-P.; Kumazawa, T.; Kondo, K.; Furuta, S.; Sato, K.; Legal Medicine 1999, 1, 231. 
28. Fustinoni, S.; Giampiccolo, R.; Pulvirenti, S.; Buratti, M.; Colombi, A.; J. Chromatogr., B 1999, 723, 105.

29. Perbellini, L.; Pasini, F.; Romani, S.; Princivalle, A.; Brugnone, F.; J. Chromatogr., B 2002, 778, 199.

30. Karaconji, I. B.; Skender, L.; Arh Hig Rada Toksikol 2007, 58, 421.

31. Schimming, E.; Levsen, K.; Kohme, C.; Schurmann, W.; Fresenius J. Anal. Chem. 1999, 363, 88.

32. Elke, K.; Jermann, E.; Begerow, J.; Dunemann, L.; J. Chromatogr., A 1998, 826, 191.

33. Ezquerro, O.; Ortiz, G.; Pons, B.; Tena, M. T.; J. Chromatogr., A 2004, 1035, 17.

34. Michulec, M.; Wardencki, W.; J. Chromatogr., A 2005, 1071, 119.

35. Koziel, J.; Jia, M.; Pawliszyn, J.; Anal. Chem. 2000, 72, 5178.

36. ANVISA, Diário Oficial da União, Resolução RE No. 899, 29 de Maio de 2003, Guia para Métodos Analíticos e Bioanalíticos, 2003.
37. FDA, U.S. Food and Drug Administration, Rockville, 2001. (incomplete)

38. Thompson, M.; Elisson, S. L. R.; Wood, R.; Pure Appl. Chem. 2002, 74, 835 .

39. Imbriani, M.; Ghittori, S.; Int. Arch. Occup. Environm. Health 2005, 78, 1 .

40. Ong, C.-N.; Lee, B.-L.; J. Chromatogr., B 1994, 660, 1.

41. Imbriani, M.; Ghittori, S.; Borlini, F.; Pezzagno, G.; Capodaglio, E.; Boll.-Soc. Ital. Biol. Sper. 1986, 60, 1919.

42. Imbriani, M.; Ghittori, S.; Pezzagno, G.; Capodaglio, E.; Int. Arch. Occup. Environm. Health 1984, 55, 33.

Received: January 21, 2009 Web Release Date: October 23, 2009 